\title{
System and Form of Kosovo Pension Fund
}

\author{
Vjosa Hajdari \\ University of Pristina / FSHAB Pejë, Kosovë \\ vjosahajdari@gmail.com
}

\section{Doi:10.5901/mjss.2013.v4n10p676}

\begin{abstract}
In this submission is presented Kosovo Pension Fund starting from froming the Fund, model, system of work, managment, forms of investments, successes and the benefits from this Fund.Data and information used for this paper are based on reports of Trust management, financial reports, publications, foreign literature and experiences. Data are checked and researched for their validation and update. In this survey conclusion is likely to be made that Kosovo Pension Fund from its forming till current days, has operated and functioned in proper and safe way during fluctuating periods of times.
\end{abstract}

Keywords: Pensin Found, Cotributors, Global Financial Crisis, Kosovo Central Bank, (OECD)

\section{Introduction}

Kosovo after war conflict in 1999 and NATO intervention, was established UN Administration and later in 2008 declared itself as independent state, during this period of time Kosovo founded Pension savings trust (Trusti). Kosovo's previous pension Funds accumulated during Yugoslav governance was looted from Serbian regime. In these circumstances Kosovo founded pension system and begin with covering beneficiaries of pension starting from age of 65 years old with benefit of $45 €$. From other point of view this amount was more as social help than a pension benefit, however this amount were delivered to all persons older than 65 years without exception ex contributors or non contributors. In 2002 after founding pension trust to ex contributors were denied right to access in their contributes because that fond was already looted from Serbian regime however new founded trust didn't follow experience of other regional countries - first pillar of system pension "Pay as you go" (PAYG), pillar which uses actual gatherings from contribution and delivers to actual beneficiaries, therefore with the Law amending Unmik regulation 2005/20 amending UNMIK regulation No. $2001 / 35$ on Kosovo pension trust was established on behalf of system of investments. With this law automatically ex contributors of ex pension fund were excluded from benefit of new Kosovo pension trust.

Kosovo mandatory pension schemes cover all salaried employers and self-employed persons, including farmers. BQK (Kosovo central bank) as supreme supervisory body of payment's in Kosovo, therefore licensed two pension funds which contain estimated value of $13.4 \%$ of GDP. These funds are "Trusti" containing around $18 \%$ of total assets value and pension found "Slovenia-Kosovo" containing $0.6 \%$ of total assets value.

\section{Kosovo pension saving trust - TRUSTI}

Kosovo Pension savings trust (Trusti) has been established in august 2002 to administer and manage mandatory and voluntary pension contributions of Kosovo's employers. Trust is governed by the Board of Directors, which consists of: five professional members with at least 10 years of professional pension expertise; two representative members, one of the other employers and employees; a representative of the Government, without voting rights, and an international representative of the International Civilian representative (ICO). All Board members are appointed by the Assembly with a 3-year term, with possibility of reelection. If the mandate of a member of the Board expires and no new member is appointed, the existing Board member will continue the mandate for ninety days.

Kosovo pension found "Trusti" is supervised by Kosovo Central Bank (BQK). Trust is made in that form that does give individually reports to contributors. Administration of these incomes is under legal responsibility of Trust. Even if the deposits are private, they can be drawn only after retirement.

All inputs in trust are invested in that way that the beneficiaries will enjoy better pension and higher income. But because of the crisis during 2008 with effect in whole World Market, this found was influenced from it and gain loss for contributors as most of this investments have been done in World Markets. 
The Trust is entitled to invest and manage resources, according to the law

Law no. 04/L-101 on Pension Funds of Kosovo gives KPST the authority and the rights of a management trustee over Pension Assets (Section 5.1), and the rights of the Trust with respect of Pension Assets shall include but not be limited to (Section 5.2):

- Conducting a selection of Asset Manager(s), Custodians, or Open-end Vehicles in accordance with this Law;;

- Executing agreements with the Asset Manager(s), Custodians, Open-end Vehicles, Accountants, Auditors, Attorneys and other service providers of the Trust;

- Demanding and receiving information from Asset Managers, Open-end Vehicles and Custodians and other service providers with respect to all transactions on behalf of the Trust including the voting of shares of stock held by the Trust;

- Adopting investment principles for the Trust;

- Removing and replacing Asset Managers, Open-end Vehicles, Custodians and other service providers of the Trust;

- Paying the proceeds of Individual Accounts for Savings Pensions to Annuity providers for the purpose of purchasing Pensions for Participants and Beneficiaries in accordance with this Law;

- Entering into agreements for the purchase, sale, lease or rental of real property or equipment necessary for the operation of the Trust;

- Hiring executive and non-executive personnel for the Trust;

- Entering into insurance agreements, including Fiduciary indemnity insurance for the Governing Board, with insurance companies licensed in Kosovo or in the member states of the OECD;

- Preparing a budget to be approved by the Governing Board;

- Charging reasonable fees on a cost basis to each Participant for the administration of Individual Accounts as approved by the Assembly on annual basis. Such fees shall not exceed $0.30 \%$ per annum, pro-rated over the year depending on the frequency of unit price calculation, and shall only be applied on invested pension assets; and

- Reimbursing all other actual expenses related to the investment of pension assets, including but not limited to: transfer charges, asset management fees and performance fees from Participant funds. ${ }^{1}$

\section{Management of Pension Found}

Management of found incomes is foreseen and invested in way that insures better and safe return of assets. The trust had a positive return of assets since year 2002 with exception of year 2008. Because of Global Financial Crisis price of the shares had been deduced on $0.8601 €$ form previous $1.2184 €$ in December 2007, and it have been marked 29.40\% fall on shares.

On next picture is given table with price movement's form 2002 till 2013.

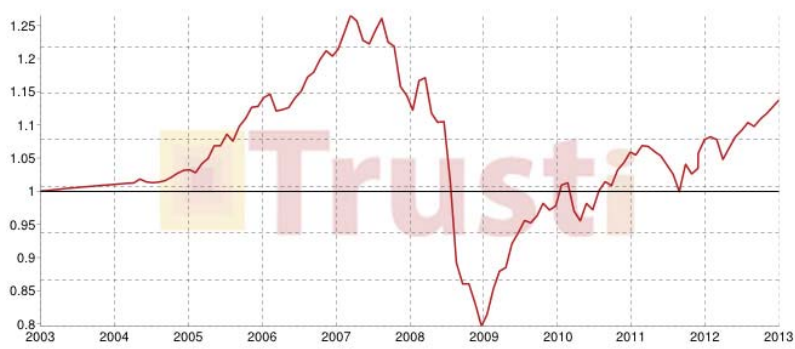

Fig.1. price of stock $2002-2013^{2}$

1 http://trusti.org/index.php/sq/per-trustin- dt.25.02.2013 23:06

2 http://trusti.org/index.php/sq/cmimi-i-aksionit?view=simple\&year=all dt.26.02.2013 19:25 
As shown on this graphic, price of shares has had growth since until 2008 therefore in 2009 cause of Global Financial Crisis had an impact on fall of share value fallowed by lose, however in second period of 2009 Trust continue having slow rise on share's.

Trust found since the first investment done in February 2003 when were invested 13 mil. $€$ on short term on marker through intermediation ABN AMRO, and after considering as safe and reliable investment, on next year were invested full $100 \%$ assets on same market. In the first period of year 2005, the investments of Trust were involved on shares (through Vanguardit), bonds (Schroders) and in credit markets (European Credit Management) beginning from second period of year 2006, while in December of 2007 on this portfolio were involved investments of value exchange (FX Concepts and Auriel Capital Management). In first period of year 2008, governing board made a decision to places on local banks some of their assets. In 2010 assets deposited in Pro Credit Bank (5 Mil €) were withdrawn after canceling agreement between. Other withdrawn was made from European Credit - Luxi found in management of ECM since 2011, this decision is been approved after considering and foreseeing incensement of risk.

Management during 2011 changed strategy of investments when a decision was made to invest $40 \%$ on share hold markets and other $60 \%$ in financial institutions with absolute return. These percentages were concluded after analyzing situation of incoming retired beneficiaries in short period of time and in long period of time.

After analyzing situation with beneficiaries of this found, decision for investing $60 \%$ in financial institutions was based on reliable and safe return of assets and guarantees covering of incoming retired beneficiaries otherwise for beneficiaries awaiting for retirement in longer period of time the $40 \%$ was invested in share hold markets.

Financial institutions that Trust invests are those operating in Kosovo and in countries members of The Organization for Economic Co-operation and Development (OECD).

Tab. 1. The following table shows the percentage of allocation of the Trust since 2003 and the 2011.

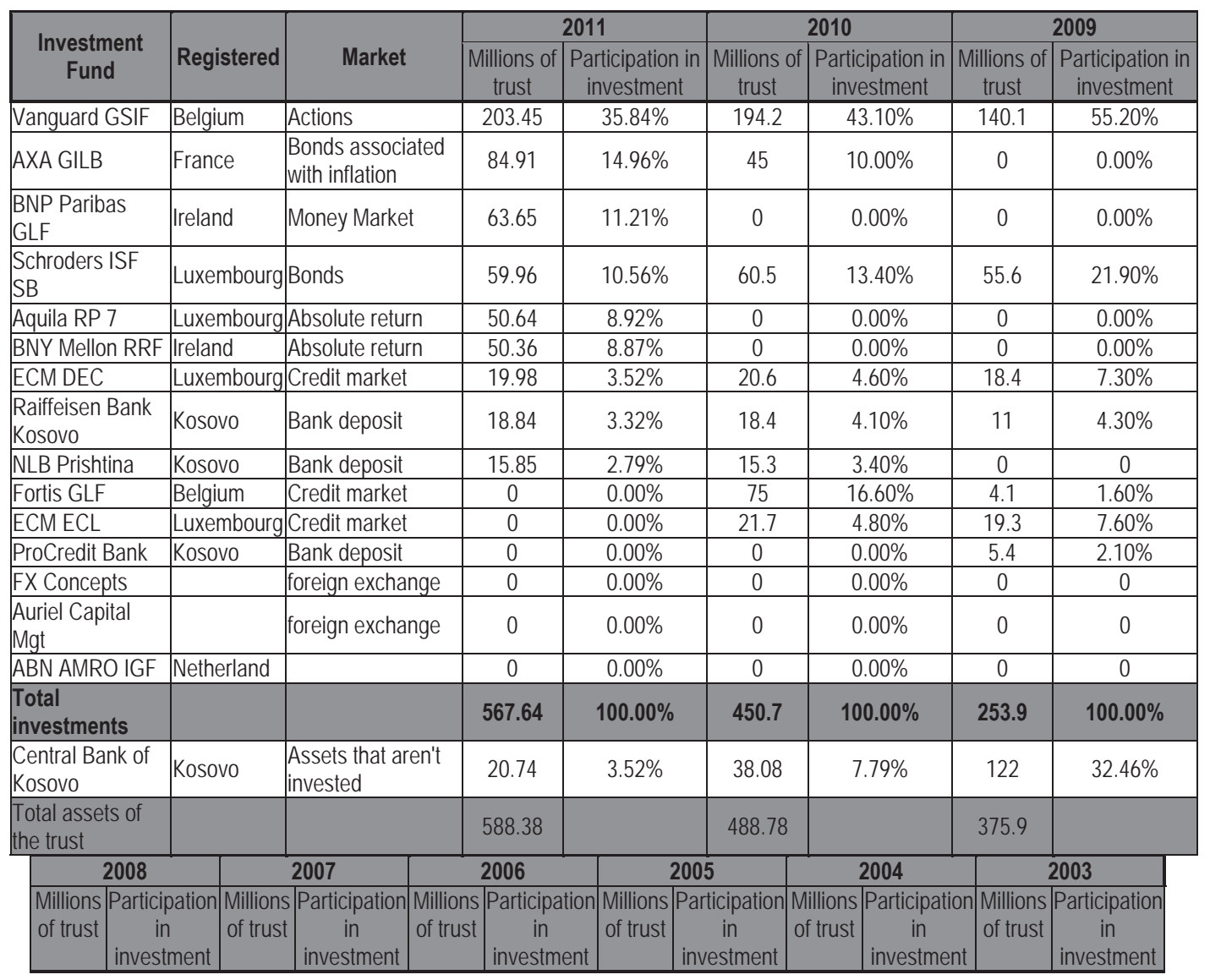




\begin{tabular}{|c|c|c|c|c|c|c|c|c|c|c|c|}
112.3 & $51.20 \%$ & 158.4 & $58.13 \%$ & 116 & 87.48 & 71.6 & $50.42 \%$ & 23.9 & $29.88 \%$ & 0 & 0 \\
\hline 0 & $0.00 \%$ & 0 & $0.00 \%$ & 0 & 0.00 & 0 & $0.00 \%$ & 0 & $0.00 \%$ & 0 & 0 \\
\hline 0 & $0.00 \%$ & 0 & $0.00 \%$ & 0 & 0.00 & 0 & $0.00 \%$ & 0 & $0.00 \%$ & 0 & 0 \\
\hline 49.2 & $22.40 \%$ & 49.9 & $18.31 \%$ & 0 & 0.00 & 0 & $0.00 \%$ & 0 & $0.00 \%$ & 0 & 0 \\
\hline 0 & $0.00 \%$ & 0 & $0.00 \%$ & 0 & 0.00 & 0 & $0.00 \%$ & 0 & $0.00 \%$ & 0 & 0 \\
\hline 0 & $0.00 \%$ & 0 & $0.00 \%$ & 0 & 0.00 & 0 & $0.00 \%$ & 0 & $0.00 \%$ & 0 & 0 \\
\hline 12.3 & $5.60 \%$ & 23.6 & $8.66 \%$ & 0 & 0.00 & 0 & $0.00 \%$ & 0 & $0.00 \%$ & 0 & 0 \\
\hline 10.4 & $4.70 \%$ & 0 & $0.00 \%$ & 0 & 0.00 & 0 & $0.00 \%$ & 0 & $0.00 \%$ & 0 & 0 \\
\hline 0 & $0.00 \%$ & 0 & $0.00 \%$ & 0 & 0.00 & 0 & $0.00 \%$ & 0 & $0.00 \%$ & 0 & 0 \\
\hline 4.1 & $1.90 \%$ & 3.9 & $1.43 \%$ & 0 & 0.00 & 0 & $0.00 \%$ & 0 & $0.00 \%$ & 0 & 0 \\
\hline 14.2 & $6.50 \%$ & 23.7 & $8.70 \%$ & 0 & 0.00 & 0 & $0.00 \%$ & 0 & $0.00 \%$ & 0 & 0 \\
\hline 5.2 & $2.40 \%$ & 0 & $0.00 \%$ & 0 & 0.00 & 0 & $0.00 \%$ & 0 & $0.00 \%$ & 0 & 0 \\
\hline 7.4 & $3.40 \%$ & 6.5 & $2.39 \%$ & 0 & 0.00 & 0 & $0.00 \%$ & 0 & $0.00 \%$ & 0 & 0 \\
\hline 4.4 & $2.00 \%$ & 6.5 & $2.39 \%$ & 0 & 0.00 & 0 & $0.00 \%$ & 0 & $0.00 \%$ & 0 & 0 \\
\hline 0 & 0 & 0 & $0.00 \%$ & 16.6 & 12.52 & 70.4 & $49.58 \%$ & 56.1 & $70.13 \%$ & 34.8 & $100.00 \%$ \\
\hline 219.5 & $100.10 \%$ & 272.5 & $100.00 \%$ & 132.6 & $100.00 \%$ & 142 & $100.00 \%$ & 80 & $100.00 \%$ & 34.8 & $100.00 \%$ \\
\hline 34.43 & $13.56 \%$ & 18.57 & $6.38 \%$ & 4.3 & 0.03 & 1.71 & $1.19 \%$ & 2.97 & $3.58 \%$ & 3.05 & $8.06 \%$ \\
\hline 253.93 & & 291.07 & & 136.9 & & 143.71 & & 82.97 & & 37.85 & \\
\hline
\end{tabular}

\section{Contributers}

Today in Kosovo are included approximately 424,170 beneficiaries contributing in Trust, and is considered that approximately 500.000 persons are employed. All this approximate number of employees aren't participating in Trust because as believed small amount of salaries and lack of responsibility from legal obligation. In this observation Kosovo pension found in comparison with other regional Founds is the poorest on the region, even so it began operating in approximately in same period of time as other regional Founds.

\begin{tabular}{|l|l|l|}
\hline Pillar I & Pillar II & Pillar III \\
\hline $\begin{array}{l}\text { Basic pension that benefits all } \\
\text { elderly people under 65 years } \\
\text { old. }\end{array}$ & $\begin{array}{l}\text { Is participated from employer and } \\
\text { employees in value of 5\% minimum } \\
\text { till 15\% maximum of total salary }\end{array}$ & $\begin{array}{l}\text { Supplementary funds were can be } \\
\text { participated voluntarily, and likely } \\
\text { participation in desired amount }\end{array}$ \\
\hline
\end{tabular}

Table 2. E shallaeve te kontributit

Contributors as shown on graphic below every year are participating in bigger number, however we can conclude that there is higher number of employees than self-employed participants in Trust. The growth between 2007 and 2008 shown on graphic, has occurred as a result of employment from (KQZ) Central Election Commission when were employed election monitors and after expiry of contract number of employees fall.

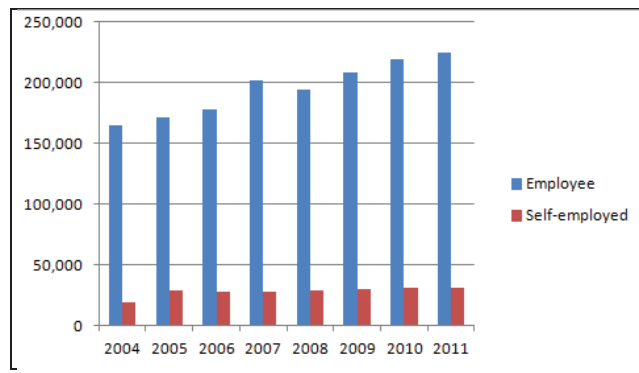

Fig.2 Contribution of participants

When we mention contributors, from the data and statistics made from Trust management possible conclusion is that the contributors from age 55-64 participate in higher number then other age groups. These statistics are shown on graphic below. 


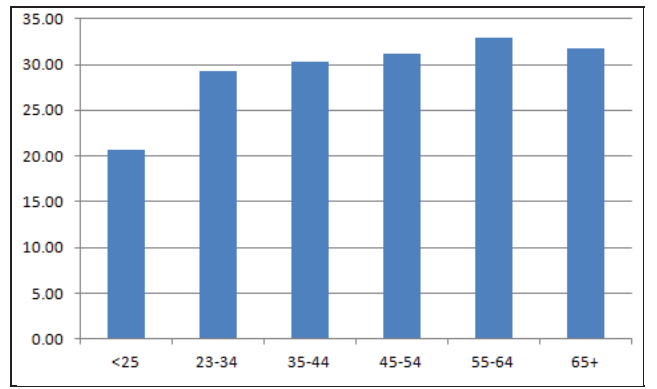

Fig.3. Contributors

Participants their benefit can acquire only when they retire and important notice is that withdraw can be made only time to time in certain amount. Other notice is that on this amount is added additional amount provided and financed from government of Kosovo to all inhabitants older than 65 years. Additional information is that in case the benefit is under $2000 €$ the beneficiary can collect immediately

\section{Conclusions}

Investing in Pension Funds is the best investment that diligent worker can make. Investments on Pension Funds are regulated by law, monitored by (BQK) Kosovo Central Bank and well managed from Trust Board. In circumstances Trust is forced to invest and exploit their recourses outside Kosovo's financial market due to absence of some instruments in financial system of Kosovo. On poor economy of Kosovo, investments from Trust funds would generate big movement on growth and development of Kosovo's economy however in near future likely will be done.

Global Financial Crisis that had negative effect on Global Financial Market, effected on Trust funds also but there are clear indicators showing that loses gained are becoming to recuperate, changing investment strategy on2008 improved situation and it was good decision for the time.

In the end recommendation is that Trust Fund must pay attention more in marketing, publishing, informing more inhabitants about benefits, safety and future of this Fund.

\section{References}

Holzmann. Robert and Guven.Ufuk: "Adequacy of Retirement Income after Pension Reforms in Central, Estern, and Southern Europe", The International Bank for Reconstruction and Development/ The World Bank, 2009.

Blake.David:"Pension Economics", John Wiley \& Sons Ltd, The Atrium, Southern Gate, Chichester, West Sussex P019 8SQ, England, 2006.

Sawant. Rajeev J.:"Infrastructure Investing managing Risk \& Rewards for Pensions Insurance Companies \& Endowments", John Wiley \& Sons, Inc., Hoboken, New Jersey, Canada, 2010.

Financial Stability Report Nr.3, Prishtinë: BQK

www.trusti.org

Trust Annual Report 2011

Trust Annual Report 2010

Trust Annual Report 2009

Trust Annual Report 2008

Trust Annual Report 2007

Trust Annual Report 2006

Trust Annual Report 2005

Trust Annual Report 2004

Trust Annual Report 2003 